DOI 10.37882/2223-2974.2020.12.30

\title{
ПРОБЛЕМНЫЕ АСПЕКТЫ ПРОЦЕДУРЫ ВНЕСУДЕБНОГО БАНКРОТСТВА ГРАЖДАН В РОССИЙСКОЙ ФЕДЕРАЦИИ
}

\section{PROBLEMATIC ASPECTS OF THE PROCEDURE OF OUT-OF-COURT BANKRUPTCY OF CITIZENS IN THE RUSSIAN FEDERATION}

\section{O. Ryabova \\ N. Kuznetsova \\ T. Matveeva \\ N. Kuznetsova}

Summary: The article is devoted to the consideration of a new type of bankruptcy of citizens in the Russian Federation - out-of-court bankruptcy. The authors analyze the possibility of successful application of the legislative framework of this procedure in modern realities. Special attention is paid to the problems of law enforcement of the relevant amendments to the Law of the Russian Federation «on insolvency (bankruptcy) of individuals». The authors ' attention is also drawn to the essence of the amendments themselves, which are the legal basis for out-of-court bankruptcy of citizens. It is concluded that, from the point of view of caring for the financial solvency of citizens and helping them in difficult life situations by releasing them from credit obligations through a simplified bankruptcy procedure, this legislative initiative is an absolute boon. However, the success of the out-of-court bankruptcy procedure in the present form is questioned by the authors.

Keywords: bankruptcy of individuals, out-of-court bankruptcy, citizens, debts.
Рябова Ольга Алексеевна

Преподаватель, ФКОУ ВО «Владимирский юридический uнсmumym ФСИН Poccuu» frau.lelya2012@yandex.ru

Кузнецова Наталья Александровна старший преподаватель, ФКОУ ВО «Владимирский юридический институт ФСИН России»

kuz1503@yandex.ru

Матвеева Тамара Павловна старший преподаватель, ФКОУ ВО «Владимирский юридический институт ФСИН России»

matveeva33@mail.ru

Кузнецова Наталья Владимировна

старший преподаватель, ФКОУ ВО «Владимирский юридический институт ФСИН России»

kuznezova-1963@mail.ru

Аннотация: Статья посвящена рассмотрению нового вида банкротства граждан в Российской Федерации - внесудебному банкротству. Авторы анализируют возможность успешного применения законодательных основ данной процедуры в современных реалиях. Особое внимание уделено проблемам правоприменения соответствующих поправок в Закон РФ «0 несостоятельности (банкротстве) физических лиц». Также внимание авторов обращено к сути самих поправок, являющихся законодательной основой внесудебного банкротства граждан. Сделан вывод 0 том, что, с точки зрения заботы 0 финансовой состоятельности граждан и помощи в трудной жизненной ситуации путем освобождения от кредитных обязательств через упрощенную процедуру банкротства, данная законодательная инициатива является безусловным благом. Однако успешность процедуры внесудебного банкротства в настоящем виде ставится авторами под сомнение.

Ключевые слова: банкротство физических лиц, внесудебное банкротство, граждане, долги.

дан пытается снизить процент уровня обязательств по займам населения и помочь избавиться от долгов. Очередной попыткой такого рода заботы стал Федеральный закон от 31 июля 2020 года №289-Ф3 «О внесении изменений в Федеральный закон «О несостоятельности (банкротстве)», который дал жизнь новому институту под названием внесудебное банкротство граждан. Поправки вступили в силу 1 сентября 2020 года.

Внесудебное банкротство граждан совершенно новое представление о процедуре банкротства. Даже одно то, что такая процедура предполагается без участия суда привлекает внимание не только граждан, попавших в трудную долговую ситуацию, но и юристов, которые изучают проблемы института банкротства в целом как с научной точки зрения, так и с практической. Аналога такой процедуры банкротства нет в юридической практике

Государство, заботясь о благосостоянии своих граж- 
иностранных государств.

В соответствии с вносимыми изменениями в Закон о банкротстве, для граждан и индивидуальных предпринимателей упрощается процедура объявления себя банкротами. При этом сама процедура осуществляется без участия судебных органов.

Закон предусматривает определенный порядок и ряд ограничений при применении процедуры банкротства. Инициировать процедуру внесудебного банкротства может гражданин, который имеет общий размер обязательств по уплате обязательных платежей, причем учитываются обязательства срок исполнения которых не наступил, обязательства по уплате алиментов и обязательств по договору поручительства, который составляет от 50000 рублей до 500000 рублей. Также в отношении такого гражданина на дату подачи заявления о банкротстве должно быть окончено исполнительное производство с пометкой о невозможности взыскания из-за отсутствия имущества у последнего и после возвращения исполнительного листа взыскателю, не возбуждено новое исполнительное производство.[2]

Если положение гражданина соответствует законодательству о внесудебном банкротстве, он может подать заявление в МФЦ, а этот орган проверит сведения о банкротящемся гражданине и в течении трех дней должен будет внести его в Единый Федеральный реестр сведений о банкротстве.[2]

Данная процедура привлекательна относительной простотой и бесплатностью. Граждане, принявшие решение признать себя банкротами и удовлетворяющие требованиям законодательства, предусмотренными для этой процедуры, могут совершенно бесплатно инициировать данный процесс.

Однако появление института внесудебного банкротства ассоциируется у многих юристов не только с достоинствами, но и недостатками, которых, на наш взгляд, несомненно больше.

При ознакомлении с действующей на настоящий момент версией норм о внесудебной процедуре банкротства создается впечатление, что поправки создавались в спешке. Это не пошло на пользу новому институту.

В первую очередь, сумма долга, который числиться за гражданином определена в пределах от 50000 до 500000 рублей. Причем, к данной сумме не относятся и не берутся во внимание штрафные санкции кредитной организации. Соответственно, если сумма больше, гражданину придется воспользоваться более трудоемкой процедурой, оговоренной в законе о банкротстве. Таким образом законодатель отграничил «судебную» задолженность от «несудебной». Практикующие юристы в данном вопросе заняли разные позиции, одни из которых считают, что сумма в 500000 рублей весьма обдуманна и приемлема, при этом заявляют о необходимости повышения в дальнейшем верхней границы хотя бы до 1500000 рублей, а другая группа считает, что нижняя граница суммы должна быть увеличена до 300000 рублей, аргументируя это тем, что денежное обязательство менее 300000 рублей дееспособный работающий гражданин может вполне погасить без объявления себя несостоятельным (банкротом), а долг свыше 3000000 рублей уже серьезная нагрузка на должника при определенных обстоятельствах, а невозможность разобраться в ситуации с долговым обязательством менее 300000 рублей говорит о нерадивости сторон договора, где одна сторона не желает платить, а другая не может пойти на уступки в случае определенных обстоятельств. Мы считаем, что при платежеспособности должника возможно вносить плату по кредитным обязательствам в рамках, оговоренных в кредитном или ином договоре, а в случае наступления обстоятельств, препятствующих выполнению обязательств со стороны должника, не имеет большой разницы будет ли это 300000, 500000 рублей или другая сумма. В данной ситуации гражданин одинаково некредитоспособен.

Следующим условием упрощенной процедуры является то, что заявление о внесении себя в реестр о банкротствах подается гражданином через МФЦ. [2] При этом гражданин может подать такое заявление как по месту жительства, так и по месту пребывания. Таким образом, для объявления себя банкротом, лицо минует обращение в суд и к финансовому управляющему, что значительно сэкономит бюджет попавшего в трудную ситуацию гражданина.

Однако, полагаем, что данные изменения не принесут желаемых результатов. Можно констатировать, что поправки лишь изменили алгоритм процедуры банкротства физических лиц и индивидуальных предпринимателей, убрав из схемы финансовых управляющих и суд. Последнее, безусловно, направлено на то, чтобы разгрузить судебную систему. Вместе с тем, правильно ли отдавать многофункциональным центрам нагрузку, связанную с такой сложной процедурой как банкротство. Критики данного подхода могут возражать против нашей позиции, обосновывая свою тем, что МФЦ досталась лишь функциональная часть работы по данной процедуре. Однако работа по проверке заявленных долгов работа весьма трудная и требующая огромного опыта.

Немаловажным моментом является и факт готовности МФЦ к наплыву желающих обанкротиться граждан. Понятно, что не будет очередей, но и вопрос для разрешения непростой. Не стоит забывать, что специалисты помимо всего заняты приемом от граждан всевозмож- 
ных заявлений по другим группам вопросов и сомнительно, что штат сотрудников МФЦ ради процедуры банкротства увеличат.

Мы склонны предположить, что такая структура как МФЦ не может являться органом, который сможет качественно провести процедуру с точки зрения разграничения граждан на тех, кто соответствует требованиям законодательства и действительно нуждается в такой процедуре и тех, кто воспользуется ситуацией и при юридическом соответствии требованиям законам, по сути решит законным способом не исполнять имеющиеся у него долговые обязательства, продолжая при этом быть вполне кредитоспособными. В судебном порядке в течении довольно продолжительного времени выясняются обстоятельства ситуации с банкротящимся гражданином, а не в течении суток, как это оговорено в поправках, посвященных процедуре внесудебного банкротства. При этом судьи, занимающиеся рассмотрением банкротных производств, имеют значительный опыт в подобных делах, чего нельзя сказать о работниках МФЦ.

Представляется, что наиболее правильным вариантом было бы создание специальных учреждений, которые могли бы спокойно и грамотно с помощью опытных специалистов, возможно из числа судей в отставке, адвокатов, осуществлять прием граждан и реализовывать процедуру внесудебного банкротства.

Если учитывать тот факт, что по сути внесудебное банкротство ни что иное, как списание безнадежных долгов, с определенными общеправовыми ограничениями, то велика вероятность того, что доступ к процедуре получат лица не совсем честные и воспользуются возможностью нажиться на кредитных обязательствах.

Не надо забывать про категорию граждан, которые будут использовать указанные поправки для осуществления своих мошеннических схем, а граждане, которые действительно, благодаря закону о банкротстве с учетом новых изменений, могут найти долгожданное облегчение от кредитного бремени, столкнуться с реальными трудностями в реализации своих прав в рамках банкротного законодательства. Ни закон о банкротстве, ни изменения в него внесенные не содержат адекватных норм по предупреждению и защите процедуры внесудебного банкротства от подобных вариантов поведения граждан. Кто сможет взять на себя ответственность по предупреждению правонарушений в этой сфере. Например, в Германии ответственность за незаконные банкротства регламентирована весьма подробно.[5] Российские законодатели не продумали реализацию закона вне бумаги в полном объеме. Хотя банкротство настолько серьезная процедура, что требует серьезных законодательных норм в качестве оснований ее применения. Необходимо понимать, что затронуты не только интересы граждан- заемщиков, но и кредитных организаций. В этой связи необходимо отметить, что законодательство о внесудебном банкротстве регламентировало права кредиторов недостаточно четко. Необходимо уяснить, что в указанной схеме банкротства отсутствует контролирующее лицо, коим является при обычной процедуре банкротства арбитражный управляющий, и соответственно, не могут отслеживаться злоупотребления со стороны банкротящихся лиц. Необходимо понимать, что внесудебное банкротство - процедура быстротечная, в связи с чем защита прав кредиторов значительно ослабляется.

Безусловно, защита граждан важнее в силу многих обстоятельств, но нарушение прав кредитных организаций не сделает чести государству с устоявшимися демократическими принципами, претендующим на звание правового государства.

Полагаем, процедура внесудебного банкротства должна быть доступна строго ограниченному списку лиц. К таким лицам необходимо отнести граждан, которые относятся к социально незащищенным слоям населения, но не всех, а лишь тех, которые действительно являются некредитоспособными в силу серьезных обстоятельств. Для этого необходимо проводить тщательную проверку финансовых возможностей гражданина, семейного положения, социального статуса, причины получения кредита. Необходимо понимать, что несмотря на трудное экономическое положение в стране и финансовые проблемы граждан, сами граждане должны быть финансово дисциплинированы и соизмерять возможности своего бюджета при планировании получения кредита от банка. Здесь значительную роль играет понимание гражданином того, что кредит - это обязательство, которое подписывается двумя сторонами и обе стороны, в свою очередь, несут обязанности по подписанному договору. Это же относится и к другим видам задолженностей граждан. Безусловно, отсутствие основ правовой грамотности приводит к неприятным последствиям, которые случаются при подписании, например, непрочитанного или прочитанного недостаточно внимательно договора или иного документа, который впоследствии становится причиной финансовой несостоятельности гражданина.

Вместе с тем, есть категории граждан, которые попали в затруднительную финансовую ситуацию в силу сложных жизненных обстоятельств уже в момент принятия решения о заключении кредитного договора. Речь идет о людях, которым необходимо дорогостоящее лечение, при отсутствии которого, возникает угроза жизни. В данных обстоятельствах можно долго рассуждать о несоблюдении государством в отношении своих граждан обязательств соблюдения прав, гарантированных Конституцией Российской Федерации.[1] Однако, когда речь идет о жизни и здоровье гражданина, его детей 
или близких родственников, то, зачастую, оформление кредитного договора с организацией - займодавцем является единственным выходом. Можно предположить, что у таких лиц нет желания подвергаться процедуре банкротства, пусть даже и в упрощенном (внесудебном) порядке, однако для них это может быть единственной возможностью избавиться от долгового бремени. Причем не только лица, здоровье и жизнь которых оказалась под угрозой, но и их родственников, которые стали участниками кредитного обязательства, получив таким способом деньги на оплату необходимого лечения. Этот пример, на наш взгляд весьма показательный, так как в нем отражена ясная и неизбежная причина получения кредита, ценой которого является жизнь и здоровье человека.

Поэтому, несмотря на малый срок действия поправок о внесудебном банкротстве, в него необходимо вносить новые.

Еще одним проблемным моментом является тот факт, что крайне сложно, при имеющихся долгах и исполнительному листу по этим долгам, должнику соответствовать требованиям законодательства о внесудебном банкротстве, так как процедура исполнения по исполнительному листу довольно долгая, при этом кредитор при возвращении ему исполнительного листа за невозможностью исполнения может оперативно инициировать повторное исполнительное производство в соответствии с законодательством об исполнительном производстве.[4] Это может длиться бесконечно долго, что существенно ухудшает возможность благополучно осуществить процедуру внесудебного банкротства лицам, которые в этом нуждаются.
Еще одним важным недостатком, на наш взгляд, является отсутствие в процедуре внесудебного банкротства «оздоравливающего» эффекта для дальнейшего финансового благополучия гражданина. Возможно, наша точка зрения в этом вопросе найдет достаточное количество оппонентов и критиков, однако мы считаем, что сам факт того, что у гражданина произошла такая ситуация, которая позволила ему привести свое финансовое положение к такому состоянию, что возникла необходимость в банкротстве, говорит о том, что, возможно, им были совершены какие - то ошибки либо стечение тяжелых обстоятельств. И то и другое не должно привести гражданина к точке невозврата, когда финансовое положение станет настолько плохим, что банкротство не даст возможности выбраться из долговой ямы. Здесь же можно добавить, как мы уже упоминали выше, что внесудебное банкротство можно сравнить со списанием безнадежного долга и это также указывает на отсутствие реабилитационных процедур для граждан, которые могли бы выправить финансовое положение гражданина в рамках процедуры внесудебного банкротства. Вероятность помощи внесудебного банкротства в ряде случаев, при отсутствии оздоровительных процедур, может оказаться для лица банкротящегося бесполезной.

Подводя итог, можно сделать вывод о том, что задуманная и реализуемая на настоящий момент процедура внесудебного банкротства граждан является хорошей поддержкой для определенного круга должников, однако те проблемы, которые имеют место, как на уровне качества правовых норм, регулирующих реализацию данного института, так и в правоприменительном поле, не достигнут желаемого результата и тех целей, для которых этот институт был создан.

\section{ЛИТЕРАТУРА}

1. Конституция Российской Федерации (принята всенародным голосованием 12 декабря 1993 года) // Российская газета. № 23725 декабря 1993.

2. Федеральный закон от 26 октября 2002 г. № 127 - Ф3 «0 несостоятельности (банкротстве)» // Российская газета от 2 ноября 2002 г. № 209 - 210.

3. Федеральный закон от 31 июля 2020 г. №289- Ф3 «0 внесении изменений в Федеральный закон «0 несостоятельности (банкротстве)» и отдельные законодательные акты РФ в части внесудебного банкротства граждан» // Российская газета от 07 августа 2020 г.

4. Федеральный закон от 2 октября 2007 г. № 229 - Ф3 «06 исполнительном производстве» (с поправками от 31 июля 2020 г.) // Российская газета» 0 0 06 октября 2007 г. № 223.

5. Чистикова Д.М. Несостоятельность (банкротство) физического лица в Германии и России // Наука и образование сегодня. - 2020 - № 2 (49) - С.51-51

6. Ц Цветкова Г.С. Институт банкротства физических лиц: мировой опыт и российская практика // Российское предпринимательство. - 2016. - Т.17. - № 15. C. $1727-1728$.

○ Рябова Ольга Алексеевна (frau.lelya2012@yandex.ru), Кузнецова Наталья Александровна (kuz1503@yandex.ru), Матвеева Тамара Павловна (matveeva33@mail.ru), Кузнецова Наталья Владимировна (kuznezova-1963@mail.ru). 